\title{
EFEKTIFITAS SISTEM TEMU KEMBALI ARSIP DIGITAL UNIVERSITAS LANCANG KUNING PEKANBARU
}

\author{
Hadira Latiar \\ Fakultas Ilmu Budaya Universitas Lancang Kuning, Pekanbaru, Indonesia \\ E-mail: hadiralatiar6@gmail.com
}

Naskah diterima: 3 Sepetember; direvisi: 13 September; disetujui: 17 September

\begin{abstract}
Abstrak
Tujuan penelitian untuk mengetahui bagaimana tingkat keefektifan software Digital Arsip 2.0 menggunakan persamaan recall-precision sebagai sarana sistem temu balik arsip digital Universitas Lancang kuning. Penelitian ini dilakukan dari bulan April-Juni 2016. Populasi dan sampel dalam penelitian adalah seluruh arsip yang telah dikelola di ruang pengelolaan arsip Universitas Lancang Kuning dengan total 2.446 dokumen. Penelitian ini menggunakan metode kualitatif dengan menganalisis data, yaitu proses mengatur urutan data, mengorganisasikannya ke dalam suatu pola, kategori dan satuan uraian dasar. Kemudian setelah data tersebut diolah dan dianalisa hingga dapat diartikan secara keseluruhan. Dalam penyajian data ini penulis membuatnya dalam bentuk tabulasi. Seluruh data kemudian digunakan untuk menjawab permasalahan yang telah dirumuskan sebelumnya. Dari hasil penelitian diketahui bahwa nilai recall memperoleh hasil cukup tinggi sedangkan nilai precision juga cukup tinggi, tetapi jumlah dokumen relevan yang ditemukan di lemari arsip menurun. Hal ini menunjukkan bahwa software Digital Arsip 2.0 memiliki kinerja cukup baik, namun terdapat temuan bahwa tatanan atau susunan dokumen di rak yang kurang baik, serta kemampuan SDM yang kurang teliti dalam proses pengelolaan arsip.
\end{abstract}

Kata Kunci: Temu Kembali Informasi, recall-precision, arsip digital, Universitas Lancang Kuning.

\begin{abstract}
The research objective was to find out how the effectiveness of Digital Archive 2.0 software uses recall-precision equations as a means of retrieving the Lancang Yellow University digital archive system. This research was conducted from April to June 2016. The population and samples in the study were all archives that had been managed in the Lancang Kuning University archive management room with a total of 2,446 documents. This research uses qualitative methods by analyzing data, namely the process of arranging data sequences, organizing them into a pattern, category and basic unit description. Then after the data is processed and analyzed until it can be interpreted as a whole. In presenting this data the author makes it in tabulation form. All data is then used to answer the problems that have been formulated previously. From the results of the study, it was found that the recall value obtained was quite high while the precision value was also quite high, but the number of relevant documents found in the file cabinet decreased. This shows that the Digital Archive 2.0 software has a pretty good performance, but there are findings that the order or arrangement of documents on the shelves is not good, as well as the ability of human resources that are less thorough in the archive management process.
\end{abstract}

Keywords: Information Retrieval, recall-precision, archive digital, lancang kuning 


\section{Pendahuluan}

Perkembangan teknologi informasi dan komunikasi diera digital semakin pesat, hal ini berdampak pada kebutuhan masyarakat terhadap informasi. Informasi menjadi komoditas sehari-hari bagi masyarakat ketika melakukan bermacam hal aktivitas dan lain sebagainya. Bermacam jenis, bentuk, dan media penyimpanan dokumen telah mengalami berubahan guna memudahkan dalam hal penyimpanan, pengelolaan, temu kembali dan penyebaran informasi. Dokumen yang dimaksud disini arsip, yaitu sesuatu rekaman kegiatan/peristiwa yang telah dilakukan atau dikerjakan. Arsip memiliki nilai guna yang tinggi khususnya terkait bermacam kegiatan, selain sebagai nilai dari informasi, arsip juga bernilai sebagai alat bukti untuk suatu pertanggungjawaban suatu kegiatan. Dalam Undang-Undang No. 43 Tahun 2007, mendefinisikan arsip sebagai: "Rekaman kegiatan atau peristiwa dalam berbagai bentuk dan media sesuai dengan perkembangan teknologi informasi yang dibuat dan diterima oleh lembaga negara, pemerintahan daerah, lembaga pendidikan, organisasi politik, organisasi kemasyarakatan, dan perorangan dalam pelaksanaan kehidupan bermasyarakat dan bernegara" (Republik Indonesia, 2007).

Di lembaga pendidikan di Indonesia, khususnya perguruan tinggi, berdasarkan hasil penelusuran masih ada yang belum memperhatikan pengelolaan arsip. Sebagain besar arsip yang dihasilkan berupa arsip berbentuk kertas (tercetak). Hal ini mengakibatkan jumlah arsip kertas semakin menumpuk, yang akan mengakibatkan bermacam masalah terkait tempat penyimpanan, dana pemeliharaan, sumber daya pengelola, sarana prasarana, dan faktor lain berakibat pada kerusakan arsip. Sehingga, pengelolaan arsip kertas akan memerlukan dana dan sumber daya yang tinggi. Adanya teknologi saat ini, menjadi solusi untuk mengelola arsip kertas secara digital atau elektronik. Dengan pengelolaan arsip secara elektronik, akan menghasilkan berbagai keuntungan, serta mempermudah proses temu kembali. Pemanfaatan perangkat komputer menjadikan arsip konvensional menjadi arsip digital atau dikenal dengan digitalisasi arsip.

Universitas Lancang Kuning adalah salah satu perguruan tinggi yang telah melakukan pengelolaan arsip secara elektronik/digital. Arsip elektronik menurut International Council of Archives "Electronic record is a record that is suitable for manipulation, transmission or processing by a digital computer" (International Council of Archives (ICA), 1997). Dari pengertian tersebut dijelaskan bahwa "arsip elektronik berupa dokumen, rekod, atau arsip dimana ketiganya bisa oleh sedemikan rupa (manipulasi), diolah menggunakan atau memanfaatkan perangkat elektronik berupa komputer. Dalam pengelolaan dokumen/arsip digital, Unilak menggunakan sebuah software bernama Digital Arsip 2.0. Saat ini, arsip yang sudah diolah sebanyak 2.446 dokumen dengan berbagai jenis dan kategori. Namun software tersebut belum pernah dilakukan evaluasi, khsusunya dalam proses temu balik informasi atau lebih dikenal Information Retrieval System (IRS). Salah satu aspek yang dinilai dalam IRS adalah nilai recall dan precision dokumen. Recall merupakan proporsi total hasil temuan dalam suatu kegiatan penelusuran informasi dalam IRS, sedangkan precision merupakan perolehan hasil temuan yang dianggap relevan bagi pengguna. Evaluasi ini diharapkan dapat mengetahui hasil penelusuran informasi arsip digital sudah sesuai dengan perhitungan nilai recall-precision. Berdasarkan pemaparan tersebut penulis berniat ingin mengetahui seberapa tinggi nilai recall-precision pada Digital Arsip 2.0 sebagai sarana temu kembali arsip di Universitas Lancang Kuning.

Dari latar belakang yang telah diuraikan sebelumnya, selanjutnya memunculkan pertanyaan yang menjadi rumusan masalah penelitian yang perlu dikaji yaitu bagaimana tingkat efektifitas sistem temu kembali arsip digital pada Digital Arsip 2.0 ditinjau dari aspek recall-precision Universitas Lancang Kuning? Sedangkan tujuan dari ini adalah sebagai bahan evaluasi sistem temu kembali informasi informasi arsip digital dari aspek recall-precision software Digital Arsip 2.0, Universitas Lancang Kuning.

\section{Tinjauan Pustaka}

Sulisyo-Basuki berpendapat bahwa temu balik/kembali informasi atau sering disebut Information Retrieval (IR) merupakan "suatu istilah generic yang acuannya adalah temu kembali informasi/dokumen atau sumber lainnya yang disimpan oleh lembaga informasi atau perpustakaan" (Sulistyo-Basuki, 1991). 
Sedangkan menurut (Salton, 1983) menjelaskan "sistem temu kembali sebagai sesuatu proses dalam mengidentifikasi serta menemukan atau memanggil (retrieve) sebuah dokumen dari suatu simpanan (file) dimana hal tersebut merupakan jawaban yang menjadi permintaan". Dari kedua penjelasan tersebut dapat disimpulkan definisi penelusuran informasi dapat diartikan sebagai suatu bagian dari proses sistem temu balik informasi (STBI) dalam rangka memenuhi kebutuhan pengguna terkait kebutuhan informasi, menggunakan alat (tool) sebagai alat bantuan penelusuran/penelusuran serta temu balik suatu informasi. (Pendit, 2007) menyatakan bahwa system temu kembali hanya bisa bekerja efektif jika pemakai melakukan tindakan-tindakan yang terpola. (Tague-Sutclife, 1996) menguraikan pola atau sistem temu kembali informasi memiliki 6 komponen yang memiliki peran masing-masing, yaitu; a) Kumpulan berbagai dokumen, b) Pengindeksan/Indeksasai, c) Kebutuhan informasi pengguna (user), d) Strategi penelusuran dokumen/informasi, e) Kumpulan dokumen yang terpanggil (recall), f) Penilaian atau evaluasi relevansi (relevance). Dapat diilustrasikan sebagai berikut:

\section{Gambar 1}

Alur Information Retrieval System (IRS)

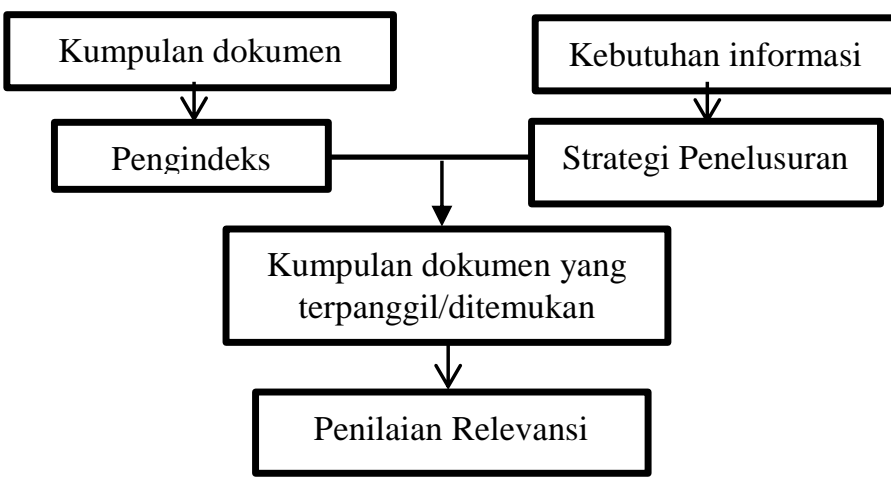

Sumber: (Tague-Sutclife, 1996)

Dari flowchart di atas dapat diuraikan bahwa yang menjadi objek data adalah dokumen yang ada di dalam sistem temu kembali yang sekaligus menjadi sumber-sumber informasi. Kumpulan dokumen pada umumnya diwakilkan dalam format indeks atau kata kunci-kata kunci, dengan tahap proses analisis dan representasi dokumen yang dilakukan oleh spesialis subjek. Proses pengindeksan nelalui tahap tertentu dengan menggunakan sistem dengan menghimpun berbagai kosa kata yang menjadi bahasa indeksyang akhirnya akan didapat informasi terorganisir. Untuk proses pencarian, pertama dimulai dengan munculnya kebutuhan informasi, dan akan menghasilkan kumpulan dokumen yang terpanggil atau ditemukan. Setelah dokumen terpanggil, pengguna selanjutnya mencocokkan dan menentukan dengan kebutuhan/keperluan. Ketika sedang melakukan penelusuran kan terjadi proses interaksi antara pemakai (user) dengan sebuah sistem (software) yang terjadi dengan interaksi langsung atau tidak langsung.

Relevansi hasil temu kembali informasi erat kaitannya dengan efektifitas. Efektifitias menurut (Alwi, 2012) adalah "kemampuan untuk memilih tujuan dengan memanfaatkan prasarana dan sarana yang tepat untuk mencapai tujuan". Pemanfaatan sebuah sistem temu kembali informasi harus menggunakan alat ukur atau parameter evaluasi supaya temuan dari dari hasil pencarian relevan atau sesuai kebutuhan pangguna. Jadi, efektifitas memiliki hubungan erat antara capaian tujuan dengan usaha pencarian. Suatu kondisi dikatakan normal atau ideal untuk menilai keefektifan sebuah sistem temu kembali menurut (Pao, 1989) jika rasio dokumen yang terpanggil (recall) dan dokumen yang relevan (precision) bersarnya sama.

Pendapat Sulistyo-Basuki (SulistyoBasuki, 1991) menjelaskan dalam sebuah sistem dapat dinilai rasio perolehan (recall) yaitu dengan membandingkan dokumen yang terpanggil dengan total dokumen relevan yang disimpan dalam sistem, untuk memperoleh rasio ketapatan (precision) yaitu membandingkan dokumen relevan dengan total dokumen/infomrasi dalam penelusuran. Dapat dipahami bahwa, nilai recall dan nilai precision adalah kondisi yang sulit ditemukan kesamaannya. Sebab, nilai recall yaitu total dokuman terpanggil oleh sistem bisa jadi tidak sesuai kebutuhan pemakai. Jadi, apabila nilai recall mendapat nilai tinggi maka nilai precision akan dijadikan indikator yang dimanfaatkan dalam menilai efektif atau tidaknya hasil temu balik informasi.

Penghitungan nilai recall menurut (Hasugian, 2006) menggunakan persamaan sebagai berikut:

$$
=\frac{\text { Total item relevall }}{\text { Total dokumen yang dimiliki }} \times 100 \%
$$

Sedangkan untuk menghitung nilai precision menggunakan persamaan: 
Recall

$=\frac{\text { Total item relevan ditemukan di rak }}{\text { Total item yang relevan diperoleh dari sistem }} \times 100 \%$

Menurut Pendit (Pendit,

"perkembangan teori penelusuran informasi, penilaian dan uji coba terhadap kemampuan suatu sistem semakin diusahakan secara optimal guna memberikan kepuasan ketika diamnfaatkan dalam kondisi yang sesungguhnya. Dalam merumuskan matriks sebagai ukuran nilai recall-precision.

Tabel 1

Ukuran Recall-Precision

\begin{tabular}{cccc}
\hline & Relevan & $\begin{array}{c}\text { Tidak } \\
\text { Relevan }\end{array}$ & Total \\
\hline Ditemukan & $\mathrm{a}$ (hits) & $\mathrm{b}$ (noise) & $\mathrm{a}+\mathrm{b}$ \\
\hline $\begin{array}{c}\text { Tidak } \\
\text { ditemukan }\end{array}$ & $\mathrm{c}$ (mises) & $\begin{array}{c}\mathrm{d} \\
(\text { rejected })\end{array}$ & $\mathrm{c}+\mathrm{d}$ \\
\hline Total & $\mathrm{a}+\mathrm{c}$ & $\mathrm{b}+\mathrm{d}$ & $\mathrm{a}+\mathrm{b}+\mathrm{c}+\mathrm{d}$ \\
\hline
\end{tabular}

Sumber: (Pendit, 2007)

Dari informasi tabel di atas, persamaan recall-precision menjadi:
Recall
$=[a /(a+c)] \times 100$
Precision
$=[a /(a+b)] \times 100$

Melalui rumus tersebut dapat dibayangkan bahwa sebuah system pengindeks harus meningkatkan recall dengan memperbesar nilai a (hits). Pada nilai a (hits) memperoleh nilai besar dapat terjadi jika jumlah dokumen yang terpanggil $(\mathrm{a}+\mathrm{c})$ oleh sistem juga besar. Semakin besar jumlah dokumen yang terpanggil $(a+c)$ semakin besar pula kemungkinan nilai $a$ (hits). Tetapi pada saat yang sama muncul kemungkinan bahwa nilai b jumlah dokumen yang tidak relevan juga semakin besar, artinya nilai precision semakin kecil. Dalam berbagai uji penilaian recallprecision sebagian besar berlawanan, yang mana jika perolehan dokumen/informasi (recall) mendapatb nilai tinggi, maka kemungkinan besar nilai ketepatan (precision) rendah.

\section{Metode Penelitian}

Penelitian ini merupakan penelitian deskriptif yang dilakukan terhadap software Arsip Digital Universitas Lancang Kuning untuk mengetahui efektifitas temu kambali arsip digital yang telah diolah dengan jumlah arsip 2.446 dokumen.

Pada penelitian ini data primer diperoleh melalui observasi di Badan Penjaminan Mutu (BPM) Unilak, kemudian penulis melakukan dokumentasi terhadap pengukuran recallprecision software Digital Arsip dengan cara melakukan praktek langsung ke lapangan. Selain itu, penulis juga melakukan wawancara tidak terstruktur terhadap penanggungjawab pengelola arsip Unilak dengan tujuan sebagai penguat data primer. Sedangkan dalam metode analisis data menggunakan persamaan recallprecision yang telah dipaparkan pada landasan teori. Langkah pertama yaitu mendaftar data sesuai dengan kategori tertentu, data tersebut kemudian dirangkum dan dipilih berdasarkan hal-hal pokok yang difokuskan pada masalah yang dianggap penting dan sesuai dengan kebutuhan penelitian. Dengan demikian data yang diperoleh dapat memberikan gambaran tentang tingkat keefektifan software Digital Arsip. Kedua, pengolahan data dan dianalisis sampai dapat diartikan secara keseluruhan. Dalam penyajian data ini, dibuat dalam bentuk tabulasi. Ketiga, penjabaran data untuk menjawab rumusan masalah, sehingga akan menjawab pertanyaan-pertanyaan dari penelitian.

\section{Hasil dan Pembahasan \\ 4.1 Hasil Penelitian}

Dari penelitian yang telah dilakukan, diperoleh beberapa temuan hasil pengamatan dan wawancara sebagai berikut:

a. Universitas Lancang Kuning telah melakukan alih media terhadap arsip cetak ke dalam bentuk digital (digitasi arsip) menggunakan software Digital Arsip. Arsip tersebut diunggah ke sistem tersebut, dikelompokkan menjadi berbagai kategori berdasarkan nama unit kerja atau lembaga di lingkungan Unilak, kemudian dikelompokkan berdasarkan jenis arsip yang dimiliki oleh masing-masing unit kerja atau lembaga.

b. Ditemukan beberapa unit kerja atau lembaga belum menyerahkan arsip-arsip tercetak, hal tersebut dikarenakan belum adanya sosialisasi ke unit kerja atau lembaga-lembaga di lingkungan Unilak.

c. Ditemukan beberapa dokumen yang tidak ditemukan pada lemari arsip ketika ditelusuri. Hal tersebut karenakan ada beberapa lembaga yang mengambil kembali dokumen dengan alasan untuk berbagai keperluan. Selain itu, ada kekhawatiran terjadi kehilangan terhadap arsip. 
d. Ditemkan beberapa dokumen yang memiliki nomor kelas sama/serupa. Hal ini dikarenakan terjadi kesalahan manusia, ketidaktelitian pegawai ketika proses pengolahan.

Data dalam penelitian ini adalah seluruh arsip digital yang telah dunggah dalam software Digital Arsip. Dalam penentuan kata kunci dalam proses temu kembali menggunakan pedoman bagan organisasi Universitas Lancang Kuning yang terdiri dari delapan besar unit kerja atau lembaga. Namun penulis hanya mengambil enam unit kerja, dikarenakan arsip-arsip keenam unit kerja tersebut telah diolah, lebih lanjut perhatiakan tabel di bawah ini:

Tabel 1

Kata Kunci Untuk Penelusuran

\begin{tabular}{|c|c|c|}
\hline No & Kategori & Kata Kunci \\
\hline 1. & $\begin{array}{l}\text { Yayasan Raja Ali } \\
\text { Haji }\end{array}$ & SK \\
\hline 2. & Rektor & $\begin{array}{l}\text { Punishment, SK, MoU, } \\
\text { LPJ Rektor }\end{array}$ \\
\hline 3. & Wakil Rektor 1 & $\begin{array}{l}\text { Tugas Belajar Dosen, } \\
\text { Sertifikasi, } \\
\text { Perpustakaan, LPPM, } \\
\text { PDPT, UPT Balai } \\
\text { Bahasa }\end{array}$ \\
\hline 4. & Wakil Rektor 2 & $\begin{array}{l}\text { Personalia, Humas, } \\
\text { Perlengkapan, } \\
\text { Koperasi, Kantin, Sawit, } \\
\text { Rusunawa, Masjid, } \\
\text { P2K2, Home Stay, Kios } \\
\text { \& Ruko, Notulen, Berita } \\
\text { acara, Pembangunan } \\
\text { gedung, Pesangon, LPJ } \\
\text { WR2, Hibah, } \\
\text { Permintaan dana, } \\
\text { Rekening koran, Audit, } \\
\text { Sarana dan Prasarana, } \\
\text { Pajak, Proposal, SPP }\end{array}$ \\
\hline 5. & Wakil Rektor 3 & $\begin{array}{l}\text { Audit, Rekapitulasi } \\
\text { Mahasiswa }\end{array}$ \\
\hline 6. & $\begin{array}{l}\text { Badan Penjamin } \\
\text { Mutu }\end{array}$ & BPM \\
\hline
\end{tabular}

Sumber: Data diolah November 2018

Dari nama dokumen tiap unit kerja kemudian diterjemahkan ke dalam beberapa kata kunci yang selanjutnya tiap kata kunci (key word) digunkan untuk query pencarian sederhana (simple Search), dalam penelitian ini untuk setiap standar terwakili oleh subyek yang digunakan sebagai kata kunci. Hasil penelitian mengungkapkan bahwa jumlah kata yang digunakan dalam penelusuran perpengarug besar terhadap hasil pencarian, yang mencakup total item yang ditemukan, item relevan atau tidak, sehingga makin kecil jumlah kata kunci yang dipakai, makin besar pula item terpanggil tetapi untuk tingkat relevansinya rendah. Berdasarkan hasil penelusuran bahwa teknik penelusuran pada software Digital Arsip hanya dapat menggunakan metode pencarian dengan menggunakan teknik yang sederhana ketika diberlakukan pada setiap field. Dengan demikian dapat diartikan bahwa pemilihan kata kunci yang digunakan dalam proses tersebut akan melakukan proses pencarian ke dalam database yang kemudian akan ditemukan dan ditampilkan kolom tampilan.

\subsection{Pembahasan}

Sebelum mengukur tingkat keefektifan, ada beberapa langkah penggunaan software Digital Arsip terkait penelusuran dokumen, yaitu:

a. Login

Dengan mengisi kolom Kode Pengguna menggunakan kata kunci "arsip", mengisi kolom Kode Sandi sesuai hak akses, pilih "Universitas" pada kolom Akses Publik, kemudian KLIK Login, seperti pada gambar berikut:

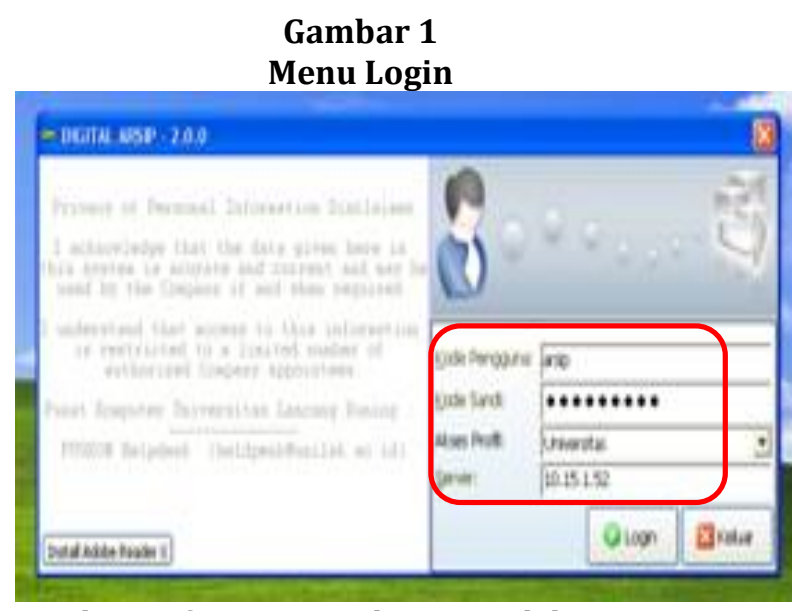

Sumber: Software Digital Arsip Unilak

b. Setelah berhasil Login, muncul tampilan berikut: 
Gambar 2

Tampilan Software Digital Arsip 2.0

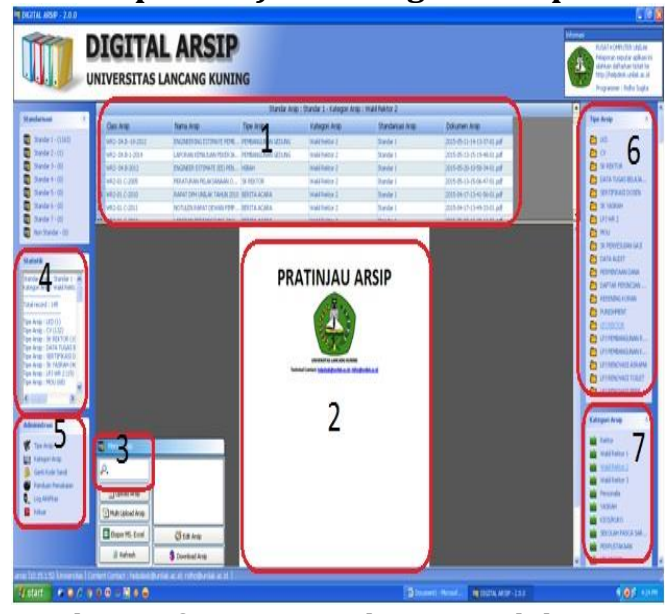

Sumber: Software Digital Arsip Unilak

Keterangan:

1. Kolom yang menampilkan kumpulan dokumen yang terpanggil

2. Kolom yang menampilkan dokumen lebih spesifik dengan format PDF

3. Menu pencarian/penelusuran

4. Menu Statistik

5. Menu administrasi

6. Menu Tipe Arsip, dan

7. Menu Kategori Arsip.

c. Langkah selanjutnya adalah memasukkan kata kunci pada kolom pencarian, kemudian KLIK Enter.

d. Dokumen akan terpanggil akan muncul pada kolom

\section{Recall-Precision}

Hasil dari perhitungan persamaan recall-precision kemudian ditampilkan dalam tabel berikut:

Tabel 2

Hasil Penelusuran

\begin{tabular}{ccccccc}
\hline Keyword & $\begin{array}{c}\text { Dok } \\
\text { Rele } \\
\text { van }\end{array}$ & $\begin{array}{c}\text { Perol } \\
\text { ehan } \\
\text { Dok }\end{array}$ & $\begin{array}{c}\text { Ket } \\
\text { epat } \\
\text { an } \\
\text { Dok }\end{array}$ & $\begin{array}{c}\text { Dok } \\
\text { Rele } \\
\text { van } \\
\text { di } \\
\text { Lema } \\
\text { ri }\end{array}$ & $\begin{array}{c}\text { reca } \\
\text { Il }\end{array}$ & $\begin{array}{c}\text { preci } \\
\text { sion }\end{array}$ \\
& & \multicolumn{7}{c}{} & \\
\hline SK & 46 & 31 & 31 & 31 & 67,3 & 67,3 \\
Punishme & 18 & 15 & 14 & 14 & 83,3 & 77,7 \\
nt & & & & & & \\
SK & 182 & 180 & 179 & 179 & 98,9 & 98,3 \\
MoU & 68 & 0 & 0 & 0 & 0 & 0 \\
LPJ & 3 & 1 & 1 & 1 & 33,3 & 33,3 \\
Rektor & & & & & &
\end{tabular}

$\begin{array}{ccccccc}\text { Tugas } & 1 & 1 & 1 & 0 & 100 & 100 \\ \text { belajar } & & & & & & \\ \text { Dosen } & & & & & & \\ \text { Sertifikasi } & 47 & 47 & 47 & 0 & 100 & 100 \\ \text { LPPM } & 475 & 470 & 470 & 470 & 98,9 & 98,9 \\ \text { UPT } & 3 & 0 & 0 & 0 & 0 & 0 \\ \begin{array}{c}\text { Pertanian } \\ \text { Terpadu }\end{array} & & & & & & \\ \text { Perlengka } & 3 & 3 & 3 & 3 & 100 & 100 \\ \text { pan } & & & & & & \\ \text { Sawit } & 7 & 2 & 2 & 2 & 28,5 & 28,5 \\ \text { Rusunaw } & 1 & 1 & 1 & 1 & 100 & 100 \\ \text { a } & & & & & & \\ \text { Kios \& } & 2 & 2 & 1 & 1 & 100 & 50 \\ \text { Ruko } & & & & & & \\ \text { Notulen } & 4 & 4 & 1 & 1 & 100 & 25 \\ \text { Berita } & 20 & 18 & 1 & 1 & 90 & 5 \\ \text { acara } & & & & & & \\ \text { Pembang } & 5 & 3 & 1 & 1 & 60 & 20 \\ \text { unan } & & & & & & \\ \text { Gedung } & & & & & & \\ \text { Pesangon } & 19 & 19 & 19 & 19 & 100 & 100 \\ \text { LPJ WR2 } & 28 & 15 & 15 & 15 & 53,5 & 53,5 \\ \text { Hibah } & 29 & 20 & 4 & 4 & 68,9 & 13,7 \\ \text { Perminta } & 16 & 9 & 7 & 7 & 56,2 & 43,7 \\ \text { an dana } & & & & & & \\ \text { Rekening } & 4 & 4 & 4 & 4 & 100 & 100 \\ \text { koran } & & & & & & \\ \text { Audit } & 23 & 23 & 21 & 21 & 100 & 91,3 \\ \text { Pajak } & 1 & 1 & 1 & 0 & 100 & 100 \\ \text { Proposal } & 5 & 5 & 1 & 1 & 100 & 20 \\ \quad \text { SPP } & 4 & 4 & 4 & 4 & 100 & 100 \\ \text { Audit } & 1 & 1 & 1 & 1 & 100 & 100 \\ \text { Rekapitul } & 11 & 11 & 11 & 0 & 100 & 100 \\ \text { asi } & & & & & & \\ \text { Mahasisw } & & & & & & \end{array}$

Mahasisw a

$\begin{array}{lllllll}\text { BPM } & 6 & 6 & 5 & 5 & 100 & 83,3\end{array}$

Sumber: Data diolah November 2018

Dari data di atas menunjukkan bahwa secara kuantitatif, dokumen relevan dengan jumlah terbanyak yaitu dokumen LPPM berjumlah 475, sedangkan jumlah tersedikit ialah dokumen tugas belajar dosen, rusunawa, pajak dan audit, masing-masing berjumlah 1 . Perolehan dokumen terbanyak yaitu LPPM berjumlah 470, sedangkan jumalh paling sedikit dokumen LPJ Rektor, tugas belajar, rusunawa, pajak dan audit berjumlah 1, ada beberapa dokumen yang tidak terpanggil antara lain MoU, dan UPT Pertanian Terpadu. Untuk dokumen relevan yang ditemukan di rak arsip paling banyak ialah jenis dokumen LPPM berjumlah 470 dokumen, sedangkan temuan dokumen paling sedikit yaitu jenis dokumen LPJ Rektor, Rusunawa, Kios \& Ruko, Notulen, Berita Acara, Pembangunan Gedung, Proposal dan Audit 
berjumlah 1, ada dokumen yang tidak ditemukan di rak arsip, seperti; Tugas Belajar Dosen, Sertifikasi, UPT Pertanian Terpadu, Pajak dan Rekapitulasi Mahasiswa.

Hasil pengukuran efektifitas sistem temu kembali arsip digital, diperoleh hasil pengukuran berdasarkan kata kunci-kata kunci yang telah ditentukan, yaitu nilai recall tertinggi diperoleh dari kata kunci Tugas Belajar, Sertifikasi, Perlengkapan, Rusunawa, Kios \& Ruko, Notulen, Pesangon, Permintaan dana, Rekening Koran, Audit, Pajak, Proposal, SPP, Rekapitulasi Mahasiswa dan BPM yaitu dengan nilai persentase $100 \%$, sedangkan nilai recall terendah didapat dari kata kunci MoU, UPT Pertanian Terpadu, dengan persentase $0 \%$, yang artinya dokumen yang relevan tidak terpanggil ketika ditelusuri melalui kata kunci pencarian. Untuk nilai precision tertinggi diperoleh dari kata kunci Tugas belajar Dosen, Sertifikasi, Perlengkapan, Rusunawa, Pesangon, Rekening Koran, Pajak, SPP, Audit dan Rekapitulasi Mahasiswa dengan nilai persentase $100 \%$, sedangkan nilai precision terendah ditemukan pada kata kunci MoU, UPT Pertanian Terpadu dengan nilai persentase 0\%, artinya dokumen yang terpanggil tidak relevan dengan yang dokumen yang dibutuhkan.

\section{Simpulan}

Berdasarkan hasil pembahasan, diperoleh kesimpulan bahwa perolehan nilai (recall) cukup tinggi dan nilai ketepatan (precision) cukup tinggi, namun total dokumen relevan yang ditemukan di lemari arsip menurun atau tidak berbanding lurus dengan total dokumen yang terpanggil. Hal tersebut menunjukkan bahwa software Digital Arsip 2.0 menunjukkan tampilan cukup baik, namun penjajaran dan penyusunan dokumen pada lemari arsip yang kurang baik serta kemampuan Sumber Daya Manusia/tenaga pengolah yang kurang teliti dalam mengolah arsip.

\section{Daftar Pustaka}

Alwi, H. (2012). "Kamus Besar Bahasa Indonesia" (4th ed.). Jakarta: Balai Pustaka.

Hasugian, J. (2006). Penggunaan Bahasa Ilmiah dan Kosa Kata Terkendali dalam Sistem Temu Balik Informasi Berbasis Teks. Pustaha: Uurnal Studi Perpustakaan Dan Informasi), 2(2). Retrieved from usupress.usu.ac.id/.../Pustaha Vol_2 No_ 2 Des_2006.pdf
International Council of Archives (ICA). (1997). Guide For Managing Electronic Records From An Archival Perspective. Retrieved from

http://www.ica.org/sites/default/files/IC

A Study 8 guide_eng.pdf. Diakses 15 Oktober 2018.

Pao, M. L. (1989). "Concepts of Information Retrieval". Englewood, Colorado: Libraries Unlimited.

Pendit, P. L. (2007). "Perpustakaan Digital dari A sampai Z". Jakarta: Cita Karya Karsa Mandiri.

Republik Indonesia. (2007). Undang-\{Undang\} \{Nomor\} 43 \{Tahun\} 2007 tentang \{Perpustakaan\}.

Salton, G. (1983). "Introduction to Modern Information Retrieval". New York: McGraw-Hill Book Company.

Sulistyo-Basuki. (1991). "Pengantar Ilmu Perpustakaan". Jakarta: Gramedia Pustaka Utama.

Tague-Sutclife, J. . (1996). Some Perspective on the Evaluation of Information Retrieval System. Journal of the American Society for Information Science, 47(1), 1-3. 